\title{
Closing Surge and Surge Propagation at Shinkansen Changeover Section
}

\author{
Hitoshi Hayashiya Member (JR East, h-hayashiya@jreast.co.jp) \\ Koji Ajiki Member (Railway technology research institute, ajiki@rtri.or.jp)
}

Keywords: electric railway, Shinkansen, changeover switch, changeover section, closing surge

In some substations of Shinkansen power system, there are a few reports of unusual conditions caused by the action of the changeover section. In Shin-Tabata substation, for example, the lightning arrester acts frequently and it becomes slight anxiety for daily maintenance. Through our investigation, it was clarified that the phenomena are caused by the closing surge of the vacuum switchgear without the train load. We have reported about the outline of the phenomena previously (in IPEC-Niigata 2005). In this paper, the detail of the phenomena are described and the propagation of the surge voltage on the railway transmission line and the reflection at the open end of the changeover section are apparently confirmed through both the field measurement and the computer simulation. The study of the phenomena removes the anxiety on the maintenance and leads to the more reliable Shinkansen power system.

Figure 1 shows the relation among the instantaneous voltage of the power source when the switchgear is opened and closed and the over-voltage. The amplitude of the over-voltage strongly depends on the opening and closing phase. Figure 2 shows the example of

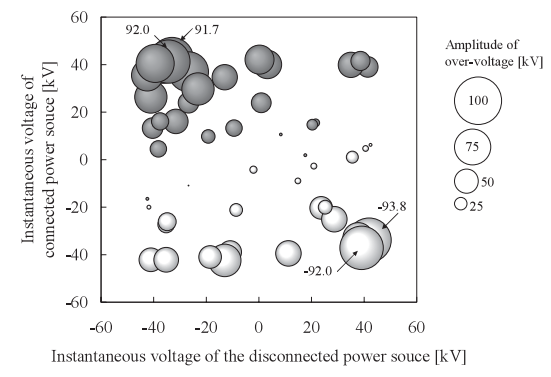

Fig. 1. Relation among the instantaneous voltage of the power source when the switchgear is opened and closed and the over-voltage
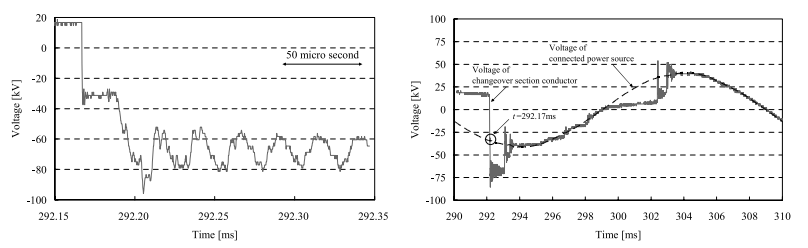

Fig. 2. Example of the voltage change of changeover section just after the closing of the switchgear without load

(left figure is zoomed waveform of the right figure) the voltage change of changeover section just after the closing of the switchgear without load. The strong over-voltage is always observed 38 micro second after the closing of the switchgear. Such a delay of the peak over-voltage is theoretically explained in connection with the surge propagation and reflection at open end. Figure 3 shows the results of the surge impedance measurement. It is also confirmed that the reflection voltage comes back to the substation 38 micro second after the injection of the impulse voltage to the power system. The measurement results of the arrester discharge current is consistent with this hypothesis.

Figure 4 shows the simulation results of the surge propagation at changeover section. The round trip of the surge voltage at changeover section is observed. It is also discovered that the rudder shape of the electric circuit of the contact wire and the messenger line which put up the contact wire causes the distortion of the wavefront waveform.

As a general concept, the location of the changeover section strongly influences on the surge propagation phenomena and causes the frequent action of the lightning arrester. Such information will be instructive for future design of the reliable Shinkansen power system structure.

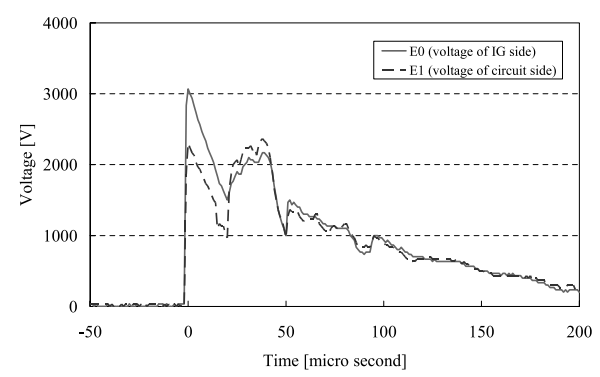

Fig. 3. Response of the changeover section circuit for injected impulse voltage

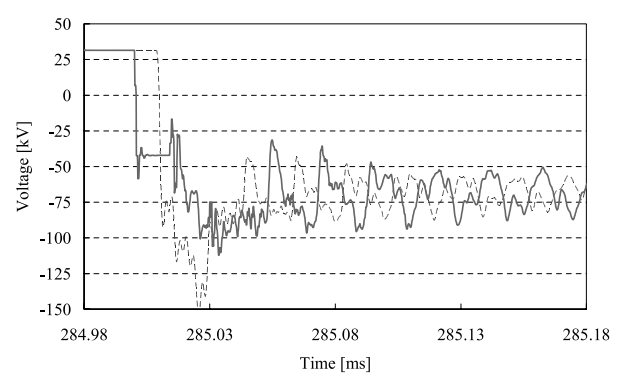

Fig. 4. Simulation results 


\section{論 文 新幹線切替セクションにおける無負荷投入過電圧とサージ伝搬 \\ 正員 林屋＼cjkstart均* 正 員 安喰 浩司 ${ }^{* *}$ \\ Closing Surge and Surge Propagation at SHINKANSEN Changeover Section

\author{
Hitoshi Hayashiya*, Member, Koji Ajiki**, Member
}

\begin{abstract}
In some substations and sectioning posts of Shinkansen power system in JR East area, the electrical transient phe-
\end{abstract} nomena when the Shinkansen train passes through the changeover section are reported during the last a few years. In this paper, the closing surge phenomena of the Shinkansen changeover section are elucidated based on both the detail measurement of the surge phenomena at substations and computer simulation. It is clarified that the surge propagation and the reflection at open end of the contact wire system cause the over-voltage at changeover section and result in the discharge of the lightning arresters at some substations.}

キーワード：電気鉄道，新幹線，切替開閉器，切替セクション，投入過電圧，サージ伝搬

Keywords: electric railway, shinkansen, changeover switch, changeover section, closing surge, surge propagation

\section{1. はじめに}

新幹線き電システムでは，変電所で三相交流を位相が 90 度異なる二回線の単相交流に変換し, これを列車に供給し ている。この際，列車に電気を供給する電源を $300 \mathrm{~ms} の$ 瞬停を伴って瞬時に切り替える切替セクションと呼ばれる 設備が数 $10 \mathrm{~km}$ 間隔で設備されている。切替セクションで は，真空開閉器を用いて電源を瞬間的に切り替える動作が 列車の通過毎に繰り返されており, そのたびに電気的な過 渡現象が発生している。このような切替セクションに関し ては，大きな事故には至らないものの，保守の立場からす ると気になる事象が各方面で発生しており，JR 東日本では 研究開発センターと各支社の現業機関と協力して, 現象の 包括的な把握と解明を行ってきた。

本論文では，これらの検討の中から，切替セクションに おける過電圧発生メカニズムについて詳細に検証した成果 を報告する。このような事象は，例えば東北新幹線新田端 変電所において避雷器の多頻度動作をもたらしており, 設 備保守上の懸案事項となっている。切替セクションにおけ る異常現象としては，これまでに鉄道総研が中心となって 報告した開閉器の負荷投入時の高周波再発弧現象 ${ }^{(1)}$ がある

\footnotetext{
*東日本旅客鉄道（株）JR 東日本研究開発センター

厂 331-8513 さいたま市北区日進町 2-0

Technical Center, R\&D Center of JR East Group

2-0, Nisshin, Kita-ku, Saitama 331-8513

** 財団法人鉄道総合技術研究所電力技術研究部

厂 185-8540 国分寺市光町 2-8-38

Power Supply Technology Division, RTRI

2-89-38, Hikari-cho, Kokubunji 185-8540
}

が，今回の調査の結果，これとは異なる真空開閉器の無負 荷投入時にも過電圧が発生し, これが避雷器の多頻度動作 をもたらしていること, その背景には切替セクションにお けるサージ伝搬現象があること, セクション配置や架線構 成がその現象に大きく寄与することなどがフィールドにお ける測定やき電系統の過渡現象シミュレーションにより明 らかとなった。切替セクションにおける無負荷投入過電圧 現象の概要については, 既に文献 (1)にて報告したが, 本論 文ではその原因についてき電システムにおける進行波の伝 搬現象を明確に捕らえる測定データに基づき, 現象論を詳 細にまとめた。無負荷投入時にもある程度の過電圧が発生 することはこれまでにもおよそ認知されていたが，その現 象を切替セクションにおける進行波の伝搬と絡めて厳密に 検討・報告した事例はこれまでになく，実測・シミュレー ションの両面から詳細に現象を説明することが出来た。

まず第 2 章では新幹線き電システムおよび切替セクショ ンの概要についてまとめ, これまでの研究例などについて 紹介する。第 3 章では無負荷投入過電圧の発生状況を実測 した結果について，第 4 章では検討に資するために行った サージインピーダンス測定試験結果についてまとめる。第 5 章では,これらの検証を裏付けるために行ったき電系統過 渡現象シミュレーション結果について述べる。

\section{2. 切替セクションと過電圧現象}

〈2・1〉切替セクション 単相交流を電源とする新幹線 のき電システムでは, 変電所において電力会社から受電し た三相交流を，スコット変圧器もしくは変形ウッドブリッ ジ変圧器を用いて位相が 90 度異なる二回線の単相交流に 
変換して列車に電気を供給している。このような変電所は, $\mathrm{JR}$ 東日本管内の東北・上越・長野新幹線では 30〜 $60 \mathrm{~km}$ 毎 に設備されており, 変電所箇所では列車が位相の異なる電 源間を移動するために，切替セクションと呼ばれる設備が 設けられている。また, 変電所と変電所の中間部では, 異 電源の突き合わせとなるため, 同様に切替セクションが設 けられている。

切替セクションの構成概要を図 1 に示す。約 $1 \mathrm{~km}$ に渡 る切替セクション部に列車が進入したことを軌道回路で検 出し, (1)開閉器 (VCB) A を開放, (2)約 $300 \mathrm{~ms}$ 後に開閉器 $\mathrm{B}$ を投入，により列車に供給される電力が図 1 の場合では $\mathrm{M}$ 座から $\mathrm{T}$ 座に切り替えられる。ここで $\mathrm{M}$ 座， $\mathrm{T}$ 座とは スコット変圧器により三相交流から変換された二回線の単 相交流で，位相が 90 度異なっている。さらに列車通過後に は次の列車に備えるため, 列車が切替セクションから脱出 したことを同じく軌道回路により検出すると, (3)開閉器 $\mathrm{B}$ を開放，(4)約 $300 \mathrm{~ms}$ 後に開閉器 $\mathrm{A}$ を投入，の手続きを行 う。このように, 列車の通過に伴い, 真空開閉器の開閉動 作により四回のき電回路構成の変更を行う。

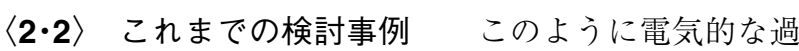
渡現象に多頻度でさらされる切替セクションにおいては， これまでも幾つかの技術革新が行われてきている。

持永らは, 新幹線切替セクションへの真空開閉器の導入 以来発生していた 0 系新幹線車両の主変圧器故障について, 切替開閉器投入時に車両主変圧器と真空開閉器による高周 波再発弧振動現象が発生することを突き止め，その原因を 解明する研究および対策の提案を行った ${ }^{(2)}$ 。

安喰らは, 文献 (3) において車両変圧器の突流を防止す るための投入制御機能を持つ静止型切替開閉器の研究を報 告しており，良好な試験結果が得られており，最近では東 海旅客鉄道が実用化に向けた開発を推進している ${ }^{(8)}$ 。また, 文献(4)においては，切替セクションにおける過渡現象に 伴って発生する可能性のある開閉器の極間短絡故障につい て, 現象解析を行うとともに新しい故障検出継電器の開発 を行った。この故障検出継電器は既に実システムにおいて 警報装置として水平展開されており，実用に供されている。 本論文では, 文献 (2) の現象と似た過電圧現象を解明し

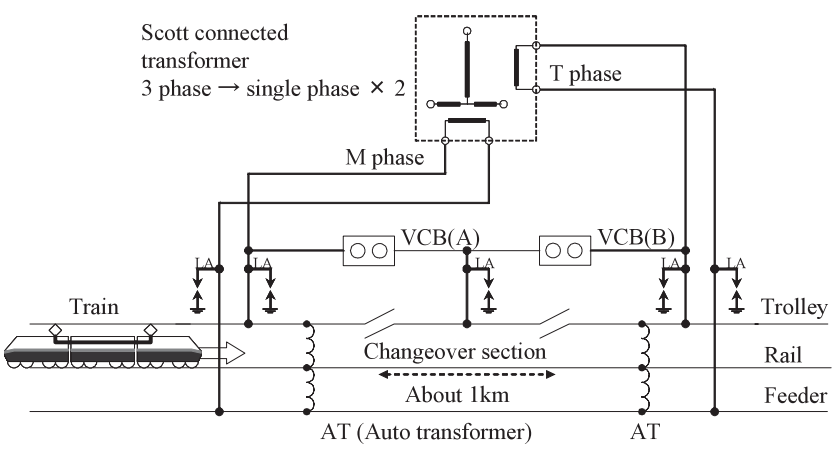

図 1 切替セクションの構成

Fig. 1. Configuration of the changeover section.
ているが，前節で述べた切替開閉器の手順で言えば，高周 波再発弧現象は(2)の列車通過時の負荷投入時に発生する過 電圧現象であるのに対し, 本論文で対象とする現象は(4)の 列車通過後の無負荷投入過電圧現象である。

$\langle\mathbf{2} \cdot \mathbf{3}\rangle$ 避雷器多頻度動作 1 章でも触れたように, 切 替セクションにおいては開閉器の開閉による過渡現象に基 づくと思われる特異な事象が幾つか発生している。その一 例として東北新幹線新田端変電所では, 上り線および下り 線において，ともに中セクションに接続された避雷器のみ が，一日あたりいずれも平均 3～5 回程度，多い日には 10 回以上も動作する状況が継続している。通常の電力用避雷 器では, 避雷器が放電電荷量は僅かであるものの多頻度で 動作する事象は見られず，また，2001 年には新田端変電所 で避雷器の地絡事故が発生した経緯もあり, 保守上の懸案 事項となっている。

新田端変電所が他の変電所と異なる点, 即ち, 新田端変 電所においてのみこのような現象が顕在化しうる要因を列 記すると下記の通りであり, それらの原因を特定するため のフィールド測定を，他の新幹線変電所およびき電区分所 での測定との比較なども含めて行ってきた。

- 変電機器が GIS 化されている。これにより変電所内母 線等の静電容量が大きくなると供に, 架空のき電引き 出し線との境界部にインピーダンスの変移点を持つ。

- 通常は変電所直近に設備される $1 \mathrm{~km}$ ほどの切替セク ション区間が，変電所からおよそ $3 \mathrm{~km}$ 離れた位置に 設備されている。

- 東京方面のき電方式が通常の AT き電方式ではなく, 同 軸き電ケーブル方式をとっている。このため, き電回 路の回路定数が特殊である。

・ JR 東日本における新幹線ネットワークのボトルネック に位置するため他の変電所より列車負荷本数が多く, 下り線は全ての列車が力行状態で通過すると同時に, 多くの場合ターミナル駅に停車中の列車負荷を抱える。 これらのうち, 今回の一連の検討の結果, 二番目の切替 セクションが遠方に設備されていることが避雷器動作の要 因であることが解明され，これらの過程について 3 章以降 にまとめる。

\section{3. 無負荷投入過電圧現象}

〈3・1〉 過電圧測定 新幹線切替セクションにおける無 負荷投入過電圧の発生状況を確認するため, 東北新幹線新 田端変電所において, 夜間の列車運行のない時間帯にき電シ ステムを加圧し, 切替セクションを動作させる随時加圧試験 を行った。過電圧の測定は, 切替開閉器室の中セクション 導体部に高電圧プローブ (パルス電子技術：EP-150KP）を 接続して行い, ディジタルオシロスコープ (YOKOGAWA： DL1640L）により波形を記録した。高電圧プローブの仕様 を表 1 にまとめる。

切替セクション動作時の中セクション電圧の測定波形の 一例を図 2 に示す。図 3 は投入時の過電圧発生部分を拡大 
表示したものであるが, この場合, 絶対值にして $100 \mathrm{kV}$ 近 い過電圧が発生している。なお, 図 2, 図 3 はいずれも文 献(1)に掲載したものであるが, 本論文の論旨を分かりや すくするために再掲載した。

図 2 において, 時刻 $t=0 \mathrm{~ms}$ に一方の開閉器が無負荷開 放され，およそ $300 \mathrm{~ms}$ 後に他方の開閉器が無負荷投入され ている。このケースでは，正のピーク值付近で開閉器が開 放されたため, 中セクションには $40 \mathrm{kV}$ 近い電圧が残留し ている。続いて他方の開閉器が投入されるまでの約 $300 \mathrm{~ms}$ の間は, 中セクション導体は電気的に浮いた状態となるが, 加圧された近隣の回線からの静電誘導を受けるために正弦 波状の電圧振動が見られるとともに，わずかな漏れ抵抗を 介して電荷が放電されるために徐々に直流電位が低下して いく。やがて他方の開閉器が投入されるが，このケースで

表 1 高電圧プローブの仕様

Table 1. Specifications of high voltage probe.

\begin{tabular}{|l|l|}
\hline Maximum input voltage & DC.100kV, Pulse $145 \mathrm{kV}$ \\
\hline Input resistance & $1500 \mathrm{Mohm}$ \\
\hline Input capacity & About $10 \mathrm{pF}$ \\
\hline Voltage divider ratio & $5000: 1 \pm 3 \%$ \\
\hline Frequency obi stage & DC $\sim 50 \mathrm{MHz}$ \\
\hline Rise time & Less than $10 \mathrm{~ns}$ \\
\hline
\end{tabular}

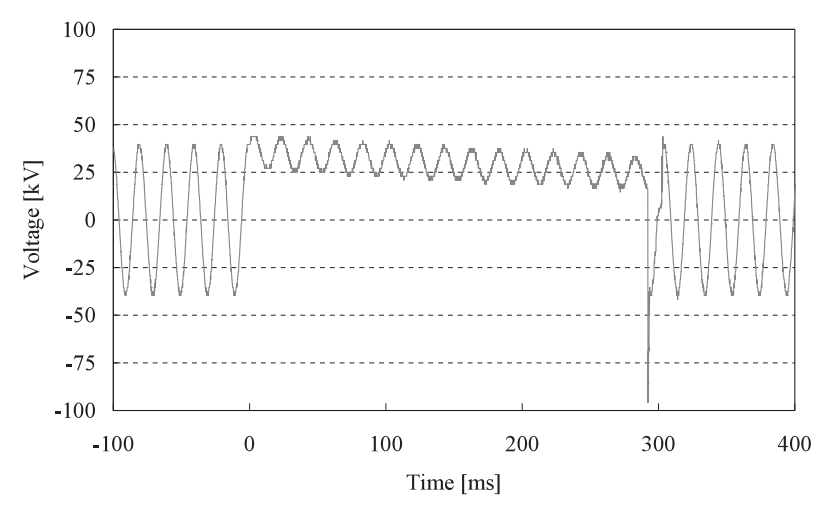

図 2 切替セクション動作時の中セクション電圧

Fig. 2. Voltage waveform with a transient over-voltage during the sequential switching.

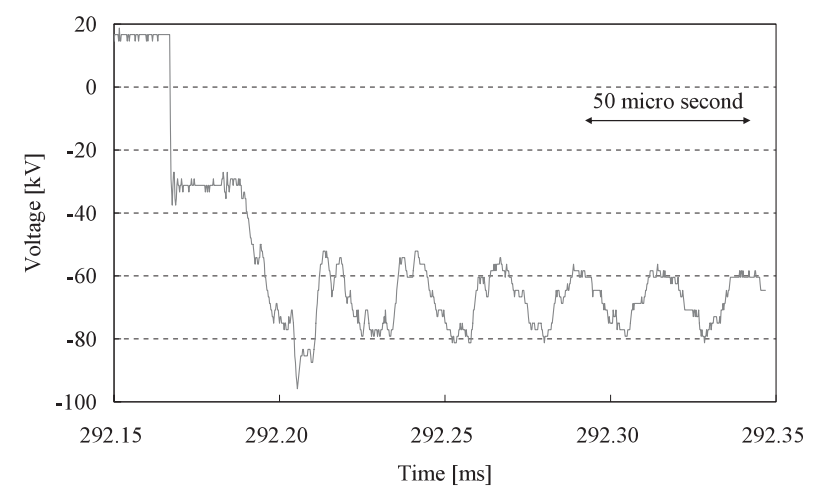

図 3 無負荷投入過電圧部分の拡大図

Fig. 3. Zoomed waveform of the wave-front in Fig. 2.
はたまたま負のピークに近い位相での投入となったため, その後の過渡現象で大きな過電圧が発生したと考えること ができる。

図 4 は横軸に開閉器開放時の開放元電源の瞬時電圧，縦 軸に投入時の投入先電源の瞬時電圧としてその直後に発生 した過電圧ピーク值の絶対值に直径が比例した円を描いた グラフである。50 回の試番中, $90 \mathrm{kV}$ 以上の過電圧を示し た四回については特に過電圧值を図中に記した。図に示す ように, 開放, 投入の位相のタイミングは制御されていない ため, 試験ごとに, あるいは列車通過ごとに発生する過渡 現象はまちまちであるが，図中，右下および左上の領域で 大きな過電圧が発生していることが分かる。すなわち，正 弦波形のピーク值付近で開閉器が開放されて, その逆位相 で投入された場合に絶対值が $90 \mathrm{kV}$ を超える過電圧が発生 していることが分かる。

$\langle\mathbf{3} \cdot \mathbf{2}\rangle$ 過電圧波形の考察 過電圧発生時の詳細な過 渡現象を見ると図 3 より, 新田端変電所での投入時の過電 圧現象においては，一度階段状に電圧が跳躍した後， $20 \mu \mathrm{s}$ ほどその電圧が維持され, その後電圧が下降（電圧の絶対 值が上昇) を開始し, 最初の跳躍からおよそ $40 \mu \mathrm{s}$ 後に過 電圧のピークを迎えることが分かる。 L と C の直列の集中 定数回路を仮定して, スイッチ投入の過渡現象を解析すれ ば，そのときの過渡波形は (1) 式で表現される。

$$
V=A \sin \left(\frac{t}{\sqrt{L C}}+\phi\right)+\frac{E}{1-\omega^{2} L C} \sin (\omega t+\theta)
$$

ここで，Aおよび $\phi$ は初期条件から求まる定数, $\omega, \theta$ は電 源角周波数および位相， $L, C$ は回路定数である。

この式において，第二項より理論的には正弦波高值の 3 倍近い過渡過電圧が発生することが予想されるが, 図 3 の 波形を考察すると，この現象はより厳密には分布定数回路 における進行波の伝搬波形であると解釈すべきである。す なわち,

(1) 開閉器の閉極に伴い極間の電界が徐々に強まり, 真空

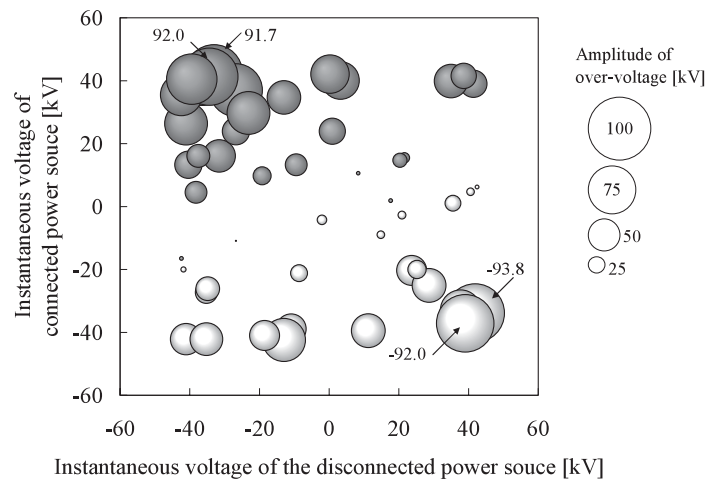

図 4 開閉器開放・投入時の電源電圧と発生 過電圧の関係

Fig. 4. Relation among the instantaneous voltage of the power source when the switchgear is opened and closed and the over-voltage. 
遮断器の接点電極上の弱点箇所で絶縁破壞し, 先行放 電が発生する（文献 (7)によれば, 真空中の絶縁破壞電 圧は電極材料にも大きく依存するが $1 \mathrm{~cm}$ あたり $70 \mathrm{kV}$ 程度，実際には材料の工夫によりもう少々絶縁耐力が あるものと考えられる)。架空導体数 $\mathrm{km}$ の中セクショ ンの静電容量は極めて微小であるために, 瞬時に中セ クションは充電され, 中セクションの電位は電源電位 と同等になり，極間の電界は消滅する。

(2) 電界消滅後は, 開閉器周辺の漂遊容量やインダクタン スからなる共振回路を電流が導通しつづけようとする が, 優れた消弧能力をもつ真空開閉器により電流零点 で先行放電は消弧, 中セクションは電気的に浮いた状 態となる。

(3) 先行放電により中セクション導体に伝えられた電荷は 進行波を形成し光速に近い速さで中セクションの導体 を伝搬し, 中セクション端部に到達する。中セクション 端部は電気的には開放端であるため, 正の反射をする。

(4) 切替セクションの設備状況により数 $\mu$ から数十 $\mu \mathrm{s}$ 後 に架線導体を伝搬してきた正の反射波は再び開閉器部 に到達し, 中セクション導体に通常の波高値の倍以上 の過電圧をもたらす。ただし，変電所やき電区分所に は避雷器が設備されているため, その制限電圧により 過電圧の絶対值は 90〜 $100 \mathrm{kV}$ に抑制される。この際, 避雷器が放電を伴う。

以下，これらを裏付ける測定結果についてまとめる。

$\langle 3 \cdot 3\rangle$ 先行放電による中セクションの充電 図 5 は 図 2 拈よび図 3 に示した無負荷投入過電圧発生時の波形を 投入先電源の 1 周期 $(20 \mathrm{~ms})$ 分と重複させて描画したもの である。投入前の中セクション導体電位は開放時の電荷が 残留しているためにおよそ+ $20 \mathrm{kV}$ (開放瞬時は $40 \mathrm{kV}$ であ るが, $300 \mathrm{~ms}$ の間に減衰している) であるが, $t=292.17 \mathrm{~ms}$ に電圧が跳躍した瞬間，投入先の電源の電位は $34.1 \mathrm{kV}$ で ある。図 3 より, この電圧值は跳躍後 $20 \mu \mathrm{s}$ 継続する電位 と等しく, この間, 開閉器の極間電位は消滅していること になる（図中，○印で示した部分が図 3 で電圧が階段状に 変化した後に電圧が平坦に維持されている時間带である)。

その後, $20 \mu \mathrm{s}$ 程度経過すると, 中セクション電位はさ らに下降（絶対值は上昇）を開始するが，その時点では既 に先行放電は消滅しているため, 中セクション電位と投入 先電源電位は乘離してゆき，再び極間電位差が生じる。そ の間も開閉器は投入過程であるために電極間隔は $1 \mathrm{~ms} に$ $0.5 \mathrm{~mm}$ 程度ずつ狭まっており, それにつれて電界強度も高 まり，再び先行放電が発生する。この繰り返しにより，断 続的に階段状の電位の変化が生じた後, やがて接点同士が 機械的に接触して, 中セクションの電位が投入先電源電位 と完全に一致する。

なお，図 5 で $t=300 \mathrm{~ms}$ 前後で再び大きな電位の乘離が 見られるが，これは投入過程に打いて一度接触した接点が 機械的にバウンドする，いわゆるチャタリングが生じてい る時間帯と一致し, この間にも先行放電の消弧, 発生に伴

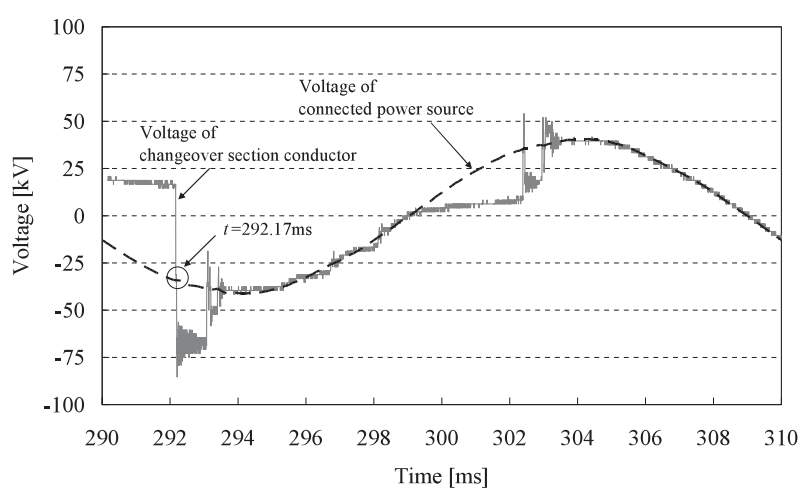

図 5 中セクション電位と投入先電位の比較

Fig. 5. Voltage of the changeover section comparison with that of the connected power source.

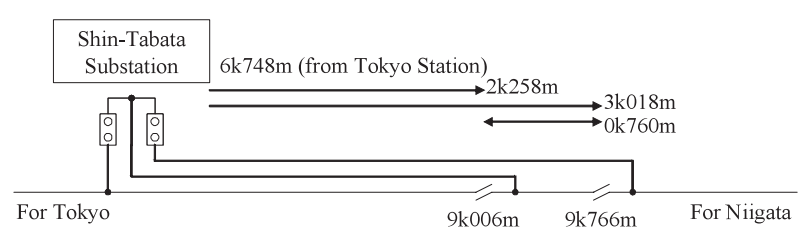

(a) In case of Shin-Tabata SS (particular case)

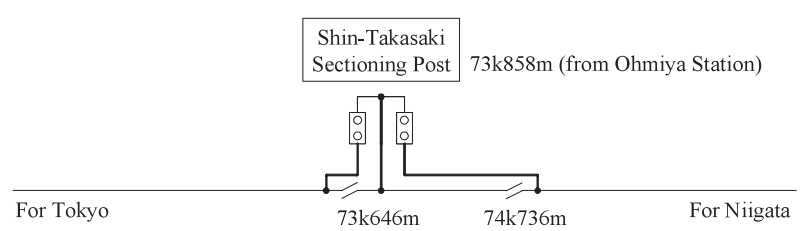

(b) In case of Shin-Takasaki SP (ordinary case)

図 6 切替セクション設備の配置

Fig. 6. Location of the changeover section.

う微小な過電圧が発生する可能性があることが確認できる。

$\langle\mathbf{3} \cdot \mathbf{4}\rangle$ 過電圧の伝搬図 6(a) は避雷器の多頻度動作 が見られる新田端変電所における変電所, および切替セク ション設備の位置関係を示したものである。通常は同図 (b) に示す上越新幹線新高崎き電区分所の例ように变電所直近 に切替セクションが設備されるが, 新田端変電所では变電 所から $3 \mathrm{~km}$ ほど大宮方面にずれた位置に切替セクション が設備されている。なお，このような変則的な設備配置と なっているのは歴史的経緯によるものであると思われるが, 現段階では明確な理由は見当たらない。

図 6(a)に示したように, 新田端変電所においては切替セ クション開放端までの変電所からの距離は $3 \mathrm{~km}$ 少々であ る。この距離を過電圧が光速に近い速度 $(300 \mathrm{~m} / \mu \mathrm{s})$ で伝 搬する進行波となって進んだとすれば，開放端へはおよそ $10 \mu \mathrm{s}$ 後に到達し, $20 \mu \mathrm{s}$ 後には再び変電所位置に戻ってく ることになり, 図 3 の電圧上昇開始時間と一致する。この ようなサージ電圧の伝搬及び開放端での反射現象が過電圧 の発生と関連していることは, 4 章で述べるサージインピー ダンス測定に打いても確認される。また，反射波の波頭が 変歪し, 過電圧のピークが約 $38 \mu \mathrm{s}$ 後に到達する点につい ては，5 章のき電系統過渡現象シミュレーションにおいて 


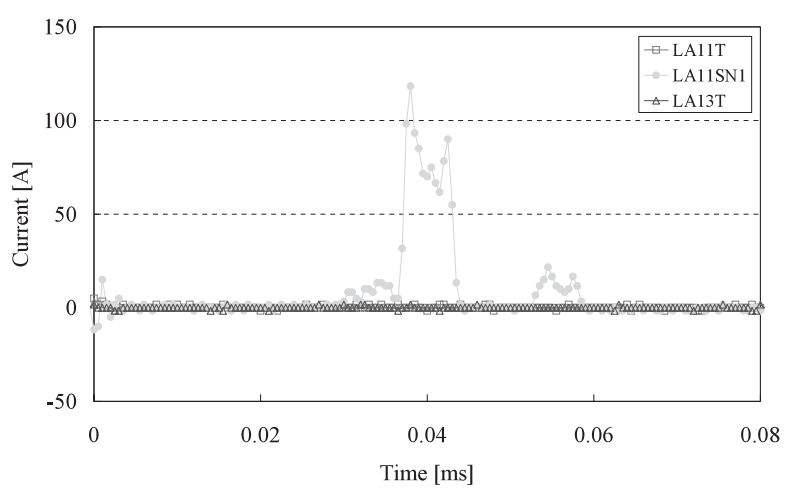

図 7 避雷器放電電流波形

Fig. 7. Waveforms of the arrester discharge current.

論じる。

$\langle\mathbf{3} \cdot \mathbf{5}\rangle$ 避雷器放電電流波形との比較 図 7 は新田端変 電所のき電線引出し部に設備された避雷器の接地線放電電 流の実測波形である。電流波形の測定には高周波応答に優 れたピアソン社製 CT (model 325：使用可能立ち上がり時

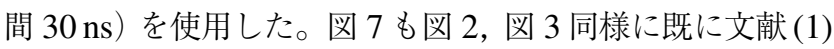
で過電圧状況として報告した結果であるが，現象論の把握 のために重要であるため，再掲載した（同時の測定ではな いため，時間軸は図 2, 図 3 と共通ではない点に注意)。凡 例中, LA11T は新田端変電所き電回線のうち下り線東京方 面に送電している回線に, LA13T は同じく下り線大宮方面 に送電している回線に, LA11SN1 は下り線中セクションに 送電している回線に取り付けられた避雷器の接地線電流波 形を意味する。このように，放電電流は中セクション回線 においてのみ計測されており，このことは，過電圧発生の 瞬時には，中セクションが東京方面および大宮方面の各回 線とは電気的には接続されていないことを示唆する。前記 のように，極間の電位差により先行放電が発生するが，瞬 時に電荷が移動するために電位差は解消され，開閉器の閉 極過程において先行放電は一旦消滅する。このため，反射 波が到達して過電圧が発生する瞬時には，中セクションは 浮いた状態となっていることを裏付けるものである。

図 7 の $t=0 \mathrm{~ms}$ を見ると，実電流波形ともスパイク状の ノイズとも判別し難い波形が見られている。これは図 3 に おいて先行放電が発生して階段状に中セクション電位が変 動した瞬間であり，その後に反射波による過電圧の絶対值 の上昇が開始して若干の放電電流が計測されるとともに, 最も過電圧が大きくなる $38 \sim 40 \mu \mathrm{s}$ 後に $100 \mathrm{~A}$ 近い最大の 放電電流が計測されており，電圧波形と電流波形で一致し た現象を示している。避雷器の非線形 V-I 特性から判断し ても，避雷器の制限電圧が $90 \mathrm{kV} \sim 100 \mathrm{kV}$ 程度で $100 \mathrm{~A} の$ 放電電流が見られることが妥当であり，また，放電電流お よび中セクション過電圧のピーク付近で $4.5 \mu \mathrm{s}$ 程度の周期 の振動波形が重畳していることなども，電流波形と電圧波 形で一致している。

$\langle\mathbf{3 \cdot 6 \rangle}$ 稀に見られる波形の解釈

図 8 は, 図 3 と同

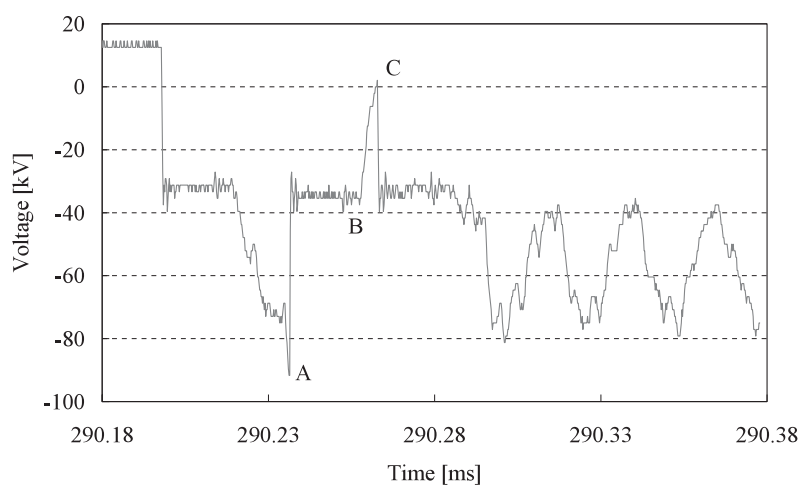

図 8 無負荷投入過電圧の拡大波形（稀に見られる ケース)

Fig. 8. Zoomed waveform of the wave-front (rare case).

様に切替開閉器の無負荷投入時に稀に見られる中セクショ ンの電位波形である。図 3 では投入後, 周期的, かつ連続 な振動波形が継続しているのに対し, 図 8 では鋸歯状の波 形が見られる。これは，一連の現象論に照らして考察する と, 進行波の到来に伴う過電圧絶対值の上昇過程で, 再び絶 縁破壊が発生し, $t=290.237 \mathrm{~ms}$ あたりで再度階段状の電 圧変化が発生する（図中 A)。放電により電極間が橋絡され たことで電荷が速やかに移動し, 一旦は電位差が解消され る。この際，一回目の先行放電時と同様に中セクション導 体を進行波が伝搬し，二回目の階段状の電圧変化からおよ そ $20 \mu \mathrm{s}$ 後の $t=290.257 \mathrm{~ms}$ に開放端から戻ってきた進行 波が到達する (図中 B)。しかし, 今度は一回目の先行放電 で生じたものとは極性が逆の進行波が到達するため，それ に伴い電圧の絶対值は下がる方向に変化し始めている。例 え中セクション電圧の絶対值が下がる方向であっても, 電 極を挟んで対向する電源の電位はこの時間オーダではほぼ 一定（図 8 の場合では $-35.4 \mathrm{kV}$ ) であるため，極間の電界 は上昇してゆき，再び先行放電による階段状の電圧変化が $t=290.263 \mathrm{~ms}$ に発生している（図中 C)。それ以降，しば らくは先行放電が発生せず，図 3 の場合と同様に進行波の 往復に伴う周期的な電圧変動が見られている。先行放電が 発生する電界は, 電極表面の微細な粗さにも左右され確率 的に決定されるため, 先行放電が途中で発生する場合とし ない場合が混在している事例である。

\section{4. サージインピーダンス測定試験}

〈4・1〉 試験回路＼cjkstart新幹線き電システムにおける過電圧 伝搬様相を確認するため，回線に雷インパルスを注入し回 路の応答を計測するサージインピーダンス測定試験を行っ た ${ }^{(5)}$ 。試験回路を図 9 に示す。インパルス電源には標準雷 インパルス発生装置を使用し, 波高值 $3 \mathrm{kV}$ 程度のインパ ルスを注入し， $100 \Omega$ の無誘導抵抗両端での電圧測定によ り注入された電流值を計測し，ディジタルオシロスコープ (YOKOGAWA：DL1640L) により回路の応答を記録した。 本試験により，被測定回路のサージインピーダンスなど 


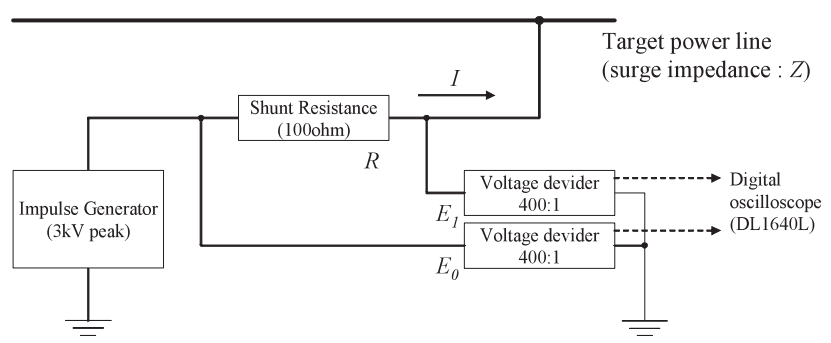

図 9 サージインピーダンス測定回路

Fig. 9. Measuring system of the surge impedance.

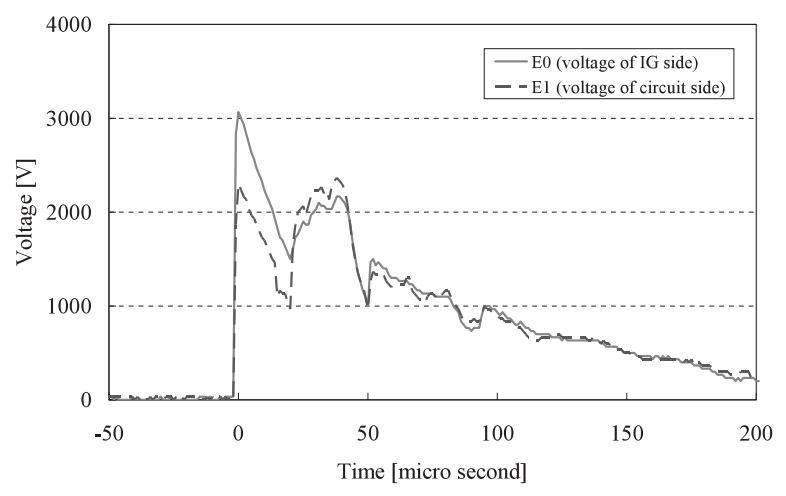

図 10 インパルス波形への中セクション回線の 応答波形

Fig. 10. Response of the changeover section circuit for injected impulse voltage.

を（2）式に基づいて求めることができるが，本論文では特 に，インパルス波形に対するき電回路の応答のみに興味が あるため，詳細は文献(5) に譲る。

$$
Z=\frac{E_{1}}{I}=\frac{E_{1}}{E_{0}-E_{1}} R
$$

$\langle\mathbf{4} \cdot \mathbf{2}\rangle$ 測定結果 東北新幹線新田端変電所の中セク ションへのき電回線へインパルス波形を注入した際の, 無 誘導抵抗両端の電圧変化の様子を図 10 に示す。この電圧波 形から (2) 式に基づいて求めたき電回線のサージインピー ダンスは $300 \Omega$ 程度と妥当な值を示すとともに, インパル ス波形を注入してから $20 \mu \mathrm{s}$ 後に無誘導抵抗の被測定回路 側の電圧である $E_{1}$ が電源側の電圧 $E_{0}$ よりも大きくなり, 即ち正の反射波が到達し, $38 \mu \mathrm{s}$ 後に $E_{1}$ の值が最大となっ ている。このことは, 中セクションの電位測定結果抢よび 避雷器接地線放電電流測定結果と整合する結果であり, 切替 セクション開放端での進行波の正の反射により中セクショ ンに過電圧が発生し, それにより変電所避雷器が動作して いることを裏付けるものである。

\section{5.き電系統過渡現象シミュレーション}

〈5・1〉解析モデルこれまでに, 新幹線切替セクショ ンにおける無負荷投入過電圧現象について, 中セクション 電位測定, 避雷器接地線放電電流測定, およびサージイン ピーダンス測定のそれぞれにおいて，切替セクション開放 端での進行波反射現象により過電圧が発生していることを

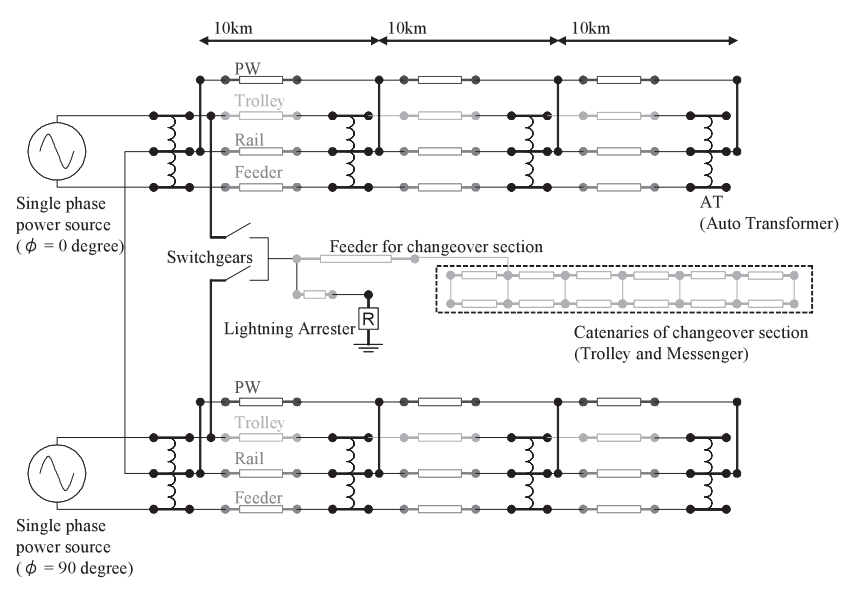

図 11 電力系統過渡現象シミュレーションモデル

Fig. 11. Model of the transient power system simulation.

裏付ける測定結果を得た。本章では，これらの現象を過渡 現象シミュレーションにより確認し，一般論へと展開する。

解析には, フランス電力公社により開発された汎用電力系 統過渡現象シミュレーションソフトウェア(๒)を用い, き電 回路を分布定数回路として取り扱った解析を行った。図 11 に解析モデルの概要を示す。実設備では電力会社から受電 した三相交流をスコット結線変圧器などにより単相二回線 に変換されるが, 解析では位相が 90 度異なる単相電源を電 源として M 座および $\mathrm{T}$ 座とし, 変電所における単巻変圧器 以降の AT き電方式の各相 ( $\mathrm{T}$ 相 (Trolley), $\mathrm{F}$ 相 (Feeder), およびレール相）をモデル化し， $30 \mathrm{~km}$ 遠方に隣接するき 電区分所が設備され，その間， $10 \mathrm{~km}$ 間隔で AT が配置さ れているものとした。中セクションについては, 配線長な どが各変電所，き電区分所により大きく異なっているため, 解析対象とする設備の電線長などを実設備に準拠した值を 用いて解析した。

$\langle\mathbf{5} \cdot \mathbf{2}\rangle$ 解析結果 中セクションが遠方に存在する新 田端変電所と, き電区分所の脇に中セクションが存在する 新高崎き電区分所のそれぞれの場合について, 図 6 中に示 した設備配置位置に準じるように中セクション引出し線導 体長および中セクションカテナリ部の導体長を設定して過 渡現象解析を行った結果を図 12 および図 13 に実線で示す。 ここで, 時刻 $t=0 \mathrm{~ms}$ に開閉器 $\mathrm{A}$ が最大振幅で開放され, その後, $t=285 \mathrm{~ms}$ に開閉器 $\mathrm{B}$ が逆極性の最大振幅で投入 された事象をシミュレーションしている。開閉器投入過程 での先行放電による電荷の移動挹よび先行放電の消滅をモ デル化するため, 開閉器 $\mathrm{B}$ は $t=285 \mathrm{~ms}$ に一度投入された 後, 電荷の移動が完全に終了している $2 \mu \mathrm{s}$ 後には再び開放 され，1 $\mathrm{ms}$ 後に再び投入されるものとした（厳密に絶縁破 壞電界などを考慮しているわけではない)。また，カテナリ 部については図 11 に示したように，パンタグラフと直接 接触するトロリ線と，それを吊架する硬銅撚線（メッセン ジャー）の並列回路としてモデル化している。実設備では これらを拉よそ $150 \mathrm{~m}$ ごとに M-T コネクタと呼ばれる架 


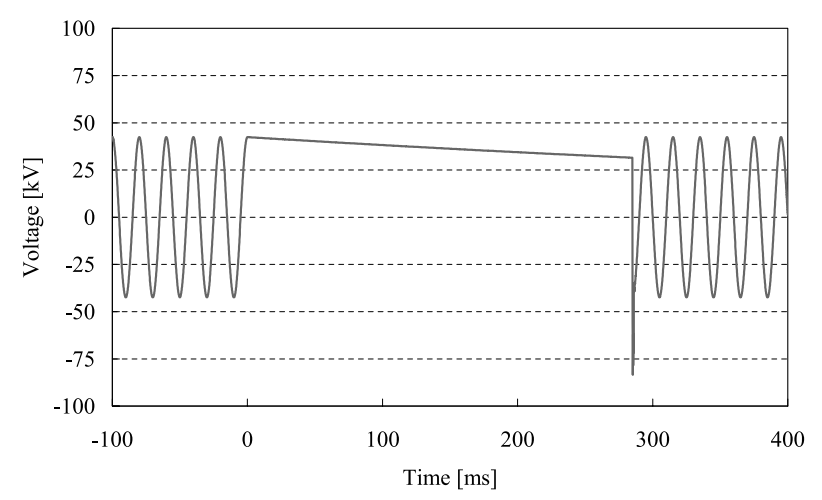

(a) Voltage waveform of the changeover section (simulation)

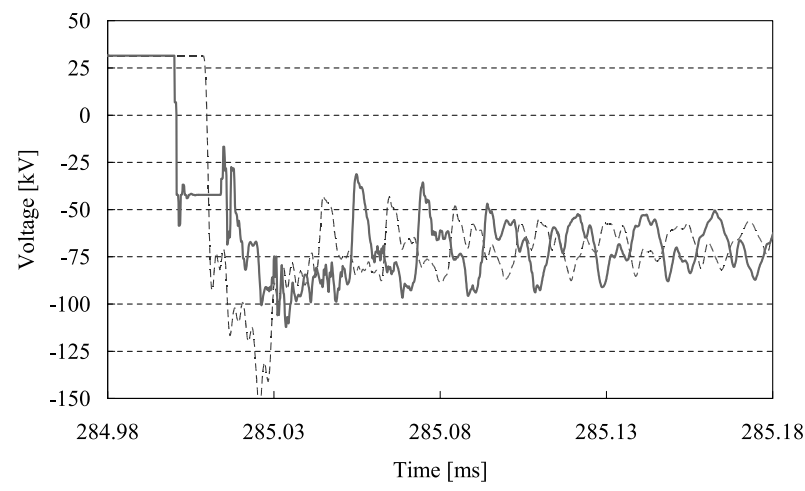

(b) Zoomed waveform of (a)

図 12 解析結果 (中セクション過電圧の時間変化： 新田端 SS の場合)

Fig. 12. Simulation results (Waveforms of the CS potential, Shin-TABATA SS case).

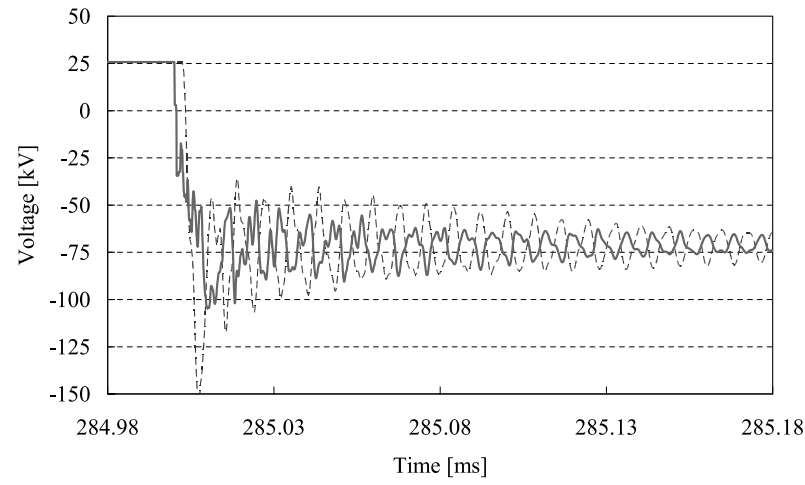

図 13 解析結果 (過電圧発生部の拡大図のみ) (中セクション過電圧の時間変化：新高崎 SP の場合) Fig. 13. Simulation results (Waveforms of the CS potential, Shin-TAKASAKI SP case).

線金具を用いて接続しており，これらには双方の電気抵抗 に従った電流が分流する事になるため，眓に示したような 梯子形回路となる。

解析的な検討を進める過程で, メッセンジャーのモデル 化を行わず，トロリ線導体のみをモデルに考慮してシミュ レーションを行うと, 図 3 にあるような, 先行放電による 階段状の電圧変動から $20 \mu \mathrm{s}$ 後から $38 \mu \mathrm{s}$ 後にかけての中セ クション電位の漸増が解析結果に現れない。即ち，開放端 で反射して来た進行波がおよそ $20 \mu \mathrm{s}$ 後に到来し，一気に

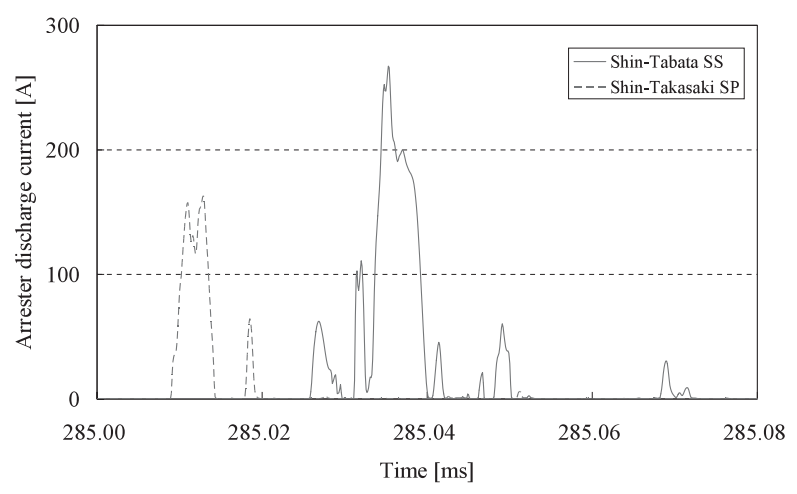

図 14 解析結果 (避雷器放電電流波形)

Fig. 14. Simulation Results (Waveforms of arrester discharge current).

ピーク電圧を迎える結果となる。これを，メッセンジャー を考慮して梯子型回路のモデルとすることで, 図 12(b)に 示したような解析結果が得られ, $20 \mu \mathrm{s}$ 後から徐々に過電圧 の絶対值が大きくなり，およそ $38 \mu \mathrm{s}$ 後に過電圧のピーク を迎えるような, 図 3 に示した実測と同様な傾向を再現す ることが出来た ${ }^{(9)}$ 。このことから, 電車線設備の梯子形回 路部を進行波が複雑に分流しつつ正の反射波が電源回路に 戻ってくるために，このような波頭部が変歪した過電圧が 計測されるものと考えられる。

図 12 および図 13 には, 変電所およびき電区分所におけ る中セクション電位を実線で記したのとあわせて, 中セク ション開放端（変電設備から遠い方）の電位変動を破線で 記した。これらより分かるように, 過電圧発生後の電圧振 動は, 分布定数回路系を進行波が往復している現象である ことが確認できる。切替セクションが変電所位置から遠方 に設備されている新田端 SS の場合は, 進行波の伝搬に時 間を要することからその往復の周期が通常の切替セクショ ンに比べて長周期となる。このため, 過電圧の継続時間が 通常よりも長くなり, 避雷器の放電電荷量が大きくなり, その結果として, 避雷器カウンタの動作に至っていると考 えられる。図 14 は図 12 および図 13 の解析における避雷 器接地線放電電流波形であるが, 無負荷投入過電圧による 避雷器の放電は切替セクションまでの距離によらずに発生 するが，その継続時間，およびトータルの放電電荷量が異 なっていることが確認できる。例えば今回の解析結果の場 合, 切替セクションが遠方に設備されている新田端 SS の 場合は放電電荷量は $1.61 \mathrm{mC}$ であるが, 通常の構成である 新高崎 $\mathrm{SP}$ の場合は $0.62 \mathrm{mC}$ であった。なお, ここでの放 電電流值が図 7 に比べてやや大きな值となっているが，こ れは避雷器の非線形特性曲線のモデル化に大きく依存する ものであると考えている。

\section{6. まとめ}

新幹線切替セクションにおいて, 列車通過後の真空開閉 器の無負荷投入に伴って発生する過電圧現象について, 進 行波理論および様々な測定結果に基づいて，詳細な検討を 
行った。その結果，以下のことが確認できた。

・切替開閉器の無負荷投入過程における先行放電により 発生した進行波電圧は, 中セクションの架線系を伝搬 し，開放端で正の反射をして戻ってくることにより， 変電所中セクション箇所に過渡的な過電圧をもたらし ており, 新田端変電所における避雷器の多頻度動作は, このような進行波による過電圧が原因である。

・一般論に展開すると, 新田端変電所のように切替セク ションが変電所から遠方に設備されている変電所では, 進行波の往復に時間を要するため過電圧の振動は長周 期となる。このために過電圧の継続時間も長くなり, また, 避雷器の放電電荷量もそれにより多くなる可能 性が, シミュレーションにより明らかとなった。

・なお, その後の調査の結果, 新田端変電所同様に切替 セクションが変電設備から遠方に設備されている新与 野き電区分所においても, 新田端変電所同様に避雷器 の多頻度動作が確認されている。

- 新田端変電所の場合, 変電所位置から中セクション開 放端までの距離は $3 \mathrm{~km} 18 \mathrm{~m}$, 同様に新与野き電区分所 の場合は $2 \mathrm{~km} 969 \mathrm{~m}$ である。一方, 上越新幹線新大宮 変電所の場合は $2 \mathrm{~km} 444 \mathrm{~m}$ 離れているが避雷器の多頻 度動作は見られていない。避雷器の制限電圧值の微妙 な違いにも大きく依存すると思われるが，開放端まで の距離が概ね $3 \mathrm{~km}$ 程度の場合に, 避雷器の多頻度動 作がもたらされている。

・単純な過電圧の往復であれば，新田端変電所の場合で は $20 \mu \mathrm{s}$ 後に反射波が到達するが，過電圧がピークを 迎えるのは $38 \mu \mathrm{s}$ 後であることが, 電圧測定, 放電電 流測定, サージインピーダンス測定の三方面から確認 された。このように，進行波の波頭が変歪することに ついては, 架線構成がメッセンジャーとトロリ線から なる梯子型回路であることに起因することが，シミュ レーションにより確認された。

なお，本論文では真空開閉器の無負荷投入過電圧現象に 特化して進行波現象をまとめたが, 負荷投入時の高周波再 発弧振動現象も詳細に考察すると進行波の伝搬がその過電 圧要因であることが分かる。今後，より統一的な解釈に向 けた検討を進めていく予定である。

\section{謝 辞}

本論文でまとめた内容は，JR 東日本の現業機関各所で 問題となっている中セクションに関わる軽微な事象につい ての包括的な検討会（通称「中セクションの安全を考える 会」)の活動の一環として行った調査・測定結果の一部をま とめたものである。これらの検討は, JR 東日本管内の各現 業機関の全面的な協力の下で実現したものであることを付 記する。

また, サージ現象論については, 工学院大学の小島宗次 教授, 元国鉄鉄道技術研究所電力研究室長の新井浩一氏, 三菱電機株式会社の斎藤勉氏，株式会社明電舍の松井芳彦 氏，東海旅客鉄道株式会社の岡井政彦氏，渡辺宗義氏，西
日本旅客鉄道株式会社の川原敬治氏らから有用な意見を頂 戴した。ここに深謝する。

(平成 17 年 5 月 27 日受付, 平成 17 年 9 月 20 日再受付)

\section{文献}

(1) H. Hayashiya, et al.: "Investigation of closing surge in Shinkansen changeover section and proposal of a novel power electronics application to avoid the surge", Proc. of International Power Electronics Conference (IPEC2005), No.45-3, pp.1534-1540 (2005)

(2) Y. Mochinaga, et al.: "Occurrence and Countermeasures for High frequency reignition oscillation in vacuum switch for Shinkansen changeover section", T. IEE Japan, Vol.111-D, No.9, pp.777-784 (1991-9) (in Japanese) 持永芳文・他：「新幹線切替え用真空開閉器の高周波再発弧振動と 抑制」, 電学論 D, 111, 9, pp.777-784 (1991-9)

(3) K. Ajiki, et al.: "Investigation of Shinkansen static changeover switch capable of suppression of exciting inrush current into transformer on train", $T$. IEE Japan, Vol.121-D, No.3, pp.340-346 (2001-3) (in Japanese) 安喰浩司・他：「車両用変圧器励磁突入電流抑制を可能とした新幹 線用静止型切替開閉器の検討」, 電学論 D, 121, 3, pp.340-346 (2001-3)

(4) K. Ajiki, et al.: "Analysis of the phenomenon associated with the short circuit of Shinkansen changeover switch and development of new type protective relay", T. IEE Japan, Vol.122-B, No.4, pp.498-505 (2002-4) (in Japanese)

安喰浩司・他：「新幹線切替開閉器電極間短絡故障に伴う回路現象 解析と故障検出継電器の開発」, 電学論 B, 122, 4, pp.498-505 (2001-4)

( 5 ) H. Hayashiya, et al.: "Surge impedance test at Shinkansen poweer system", Tech. Meeting of IEEJ, TER-05-023, pp.53-58 (2005) (in Japanese) 林屋 均・他：「新幹線き電システムに拉けるサージインピーダン 久測定」, 電気学会交通・電気鉄道研資, TER-05-023, pp.53-58 (2005)

(6) M. Yoshihara: "Advanced real-time electric network transient analyzer for personal computer", The Journal of the IEEJ, Vol.122, No.5, pp.298-300 (2002-5) (in Japanese)

吉原政昭：「沉用計算機を用いたリアルタイム瞬時值解析システム」, 電学誌, 122, 5, pp.298-300 (2002-5)

(7) I. Hayashi: High voltage and plasma engineering, Maruzen (1996) (in Japanese)

林泉：高電圧プラズマ工学, 丸善 (1996)

(8) T. Saito, et al.: "A control method to suppress exciting inrush-current of traction transformers by the static change-over switch for the Sinkansen train", 2002 National convention record, IEEJ, No.5-194, pp.265-266 (2002) (in Japanese)

斎藤 勉・他 : 「新幹線用静止型切替開閉器による車両用主変圧器 励磁突入抑制に関する検討と現車試験結果」, 平 14 電気学会全大, No.5-194, pp.265-266 (2002)

(9) H. Hayashiya: "Simulation of the surge propagation in changeover section", IEEJ Industry Appl. Soc. Conference, No.3-83 (2005) (in Japanese) 林屋 均: 「切替セクションに拈けるサージシミュレーション」, 平 17 電気学会産業応用部門大会, No.3-83 (2005)

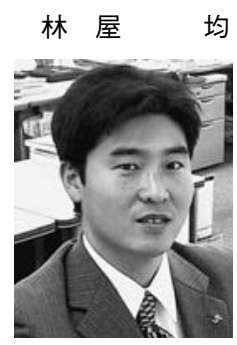

（正員） 1970 年 6 月 28 日生。1999 年 3 月東京 大学大学院博士課程修了, 同年 4 月東京大学助手 を経て, 2002 年 7 月から JR 東日本研究開発セ ンター勤務。これまでに, 磁気浮上・リニアモー 夕，プラズマ磁気閉じ込め配位の相互比較，レー ザ干渉計測などの研究に従事。現在，主に電気鉄 道分野のサージ現象やアーク現象に関する研究に 従事。博士 (工学)。日本 AEM 学会会員。

安 喰 浩 司 (正員) 1956 年 3 月 26 日生。1 979 年 3 月東京

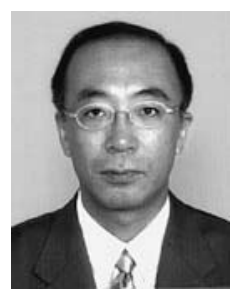
理科大学応用物理学科卒業後, 同年 4 月日本国有 鉄道入社。現在，(財) 鉄道総合技術研究所電力 技術研究部 (き電) 主任研究員。主に電気鉄道に おける高電圧・絶縁技術および交流き電回路に関 する研究に従事。技術士（電気・電子部門）。 